\title{
MUTATIONAL SCREENING OF THE NEGATIVE REGULATORY REGION OF ASTROCYTE ELEVATED GENE-1 PROMOTER IN HEPATOCELLULAR CARCINOMA PATIENTS
}

\author{
TRIAGEM MUTACIONAL DA REGIÃO REGULADORA NEGATIVA DO \\ PROMOTOR DO GENE-1 ELEVADO EM ASTROCITO EM PACIENTES COM \\ CARCINOMA HEPATOCELULAR
}

\begin{abstract}
Naghmeh GHOLIPOUR ${ }^{1}$; Sakineh MASHJOOR ${ }^{2}$; Zeinab Emruzi TUBKANLU ${ }^{1}$; Hamideh KHAJEH ${ }^{3}$; Malihe NADERI ${ }^{4}$; Nader Mansour SAMAEI ${ }^{5}$, Gholamreza MOTALLEB ${ }^{3}$

1. Department of Medical Genetics, National Institute of Genetic Engineering and Biotechnology (NIGEB), Tehran, Iran; 2. Department of Marine biology, Faculty of Marine Science and Technology, Hormozgan University, Bandar Abbas, Iran.

sakynemashjoor@gmail.com; 3. Department of Biology, Faculty of Science, University of Zabol, Zabol, Iran; 4. Department of Microbiology, Qom branch, Islamic Azad university, Qom, Iran. Branch, Islamic Azad University, Tehran, Iran; 5. Department of Human Genetic, Faculty of Medicine, Golestan University of Medical sciences, Gorgan, Iran.
\end{abstract}

\begin{abstract}
Astrocyte elevated gene-1 (AEG-1) is a positive regulator of tumorigenesis in human cancer cells. Human AEG-1 gene is located in chromosome 8q22 having 12 exons/11 introns. Chromosome 8q22 is known to be a hot spot for genomic alterations in several cancerous cells involving HCC. The aim of the study was assess association between the negative regulatory region of AEG-1 promoter mutations and genetic susceptibility to hepatocellular carcinoma. The negative regulatory region of the human AEG-1 promoter was evaluated in a total of 50 Iranian hepatocellular carcinomas (HCC) patients. For investigating AEG-1 promoter polymorphisms the PCR-sequencing method was used. In this study was found two new mutation $C>T(-633)$ and $G>C$ ( -660$)$ in the patient group. But it was not revealed the statistically significant association between any mutations in this region of the AEG-1 promoter with HCC susceptibility. According to presented data, we can say that the negative regulatory region of the AEG-1 promoter mutations did not exihibit significant relevance with hepatocellular carcinoma. We recommend further studies on the efficacy of the AEG-1 promoter in therapeutic targeting of the HCC.
\end{abstract}

KEYWORDS: Astrocyte elevated gene -1. Hepatocellular carcinoma. Mutation. Promoter. Regulatory region.

\section{INTRODUCTION}

Nearly 50,000 new cases of cancer occur annually in the Iran (MOHEBBI et al., 2008). Hepatocellular carcinoma (HCC) is the fifth most common malignancy in the world and is estimated to cause approximately half a million deaths each year (SAIEDI HOSSEINI, 2011), with a high prevalence in some of the Asian countries (ALVES et al., 2011). HCC is a tumor with rapid growth and highly vascular invasion (YOO et al., 2009a). It is also more resistant to standard chemotherapy (YOO et al., 2009a). Principal risk elements for HCC include HBV or HCV, alcoholic liver and nonalcoholic fatty liver disease (EL-SERAG, 2011). The treatment choices for HCC depend on the stages and grades of the disease (YOO et al., 2009b). Surgical resection, radiofrequency ablation, and liver transplantations are the treatments of option for localized disease (YOO et al., 2009b). Astrocyte elevated gene 1 (AEG-1), a novel oncoprotein, has been implicated in oncogenesis and cancer progression in various types of human cancers (SONG et al., 2009), also known as a positive regulator of tumorigenesis (YOO et al., 2011).
Human AEG-1 gene is located in chromosome $8 \mathrm{q} 22$ having 12 exons/11 introns. Chromosome $8 \mathrm{q} 22$ is known to be a hot spot for genomic alterations in several cancerous cells involving $\mathrm{HCC}$ and breast cancer (BERGAMASCHI et al., 2006; POON et al., 2006; YOO et al., 2011).

AEG-1 by rapid subtraction hybridization as a gene induced in primary human fetal astrocytes (PHFA) infected with HIV-1 or treated with TNF- $\alpha$ was cloned (BHUTIA et al., 2010). General localization of AEG-1 is in the cytoplasm and also detected in the ER/nuclear envelope (SUTHERLAND et al., 2004; KANG et al., 2005). But in cancerous cells, AEG-1 is revealed in the cytoplasm, on the cell membrane and in the nucleus (YOO et al., 2009a). Expression of AEG-1 in human hepatocytes was extremely low nevertheless its levels were significantly increased in HCC patients (YOO et al., 2009a). AEG-1 overexpression and inhibition in both in-vitro and in-vivo studies revealed the significance of AEG-1 in regulating several physiological processes, such as proliferation, metastasis, invasion, and gene expression (SARKAR et al., 2009). As reported by LEE et al. (2006) AEG-1 promoter in the human has 
positive (-459/-302) and negative (-738/-460) regulatory sectors (Figure. 1). In the negative regulatory regions, putative RAR- $\alpha$ and YY1 binding sites, act significantly as an inhibitor of transcription (LEE et al., 2006). As it was mentioned before, AEG-1 is overexpressed in more than $90 \%$ of hepatocellular carcinoma patients and plays a predominant role in mediating aggressive progression of HCC (YOO et al., 2009b). Thus, we predict an important role in gene suppression for AEG-1 negative promoter region, with putative RAR- $\alpha$ and YY1 binding sites, and believe its variants may be responsible for the elevation of AEG-1 expression in HCC patients. This study was performed to better understand the role of AEG-1 in hepatocarcinogenesis and aimed to investigate the association between the AEG-1 negative region promoter variant in hepatocellular carcinoma patient of Iranian population that can be a response to increased expression of this gene. To our knowledge, this is the first study analyzing tumor promoting the function of AEG-1 region that tested in the hepatocellular carcinoma patients.

\section{CASE REPORT}

The studied population comprised $50 \mathrm{HCC}$ patients and 50 healthy persons (control). Tumor samples had been surgically removed from people with HCC and these tumors marginal tissue was used as controls. The patients were recruited from some Provinces of Iran. Based on the standard pathologic, histopathologic and demographic criteria, HCC patient was diagnosed. In this study, the average age of the selected hepatocellular carcinoma patients was $59 \pm 2$ years, in which consisted of $47 \%$ female and $53 \%$ male genders and in control group was $53 \pm 2$, in which consisted of $50 \%$ female and 50\% male genders. For each subject, the informed consent was obtained.

Paraffin-embedded tissue sections were deparaffinized with $100 \%$ xylene for three times. The samples were washed five times with ethanol, to remove the residual xylene. After that, the sections were left in a $40{ }^{\circ} \mathrm{C}$ oven to dry the tissues. When tissues were dried, $500 \mu \mathrm{l}$ lysis solution (40 $\mathrm{mM}$ Tris, $1 \mathrm{mM}$ EDTA, 0.5\% Tween-20, $0.5 \mu \mathrm{g} / \mu \mathrm{l}$ proteinase $\mathrm{k}, \mathrm{pH}=8$ ) was added to each sample (VAZIRI GOHAR AND MOHAMMADI, 2009; PIKOR et al., 2011).

Genomic DNA was extracted from tissues by using the phenol/chloroform procedure (LEE et al., 2006). DNA concentration and the purity of each sample were measured by Picodrop. DNA samples were routinely stored at $-20^{\circ} \mathrm{C}$.

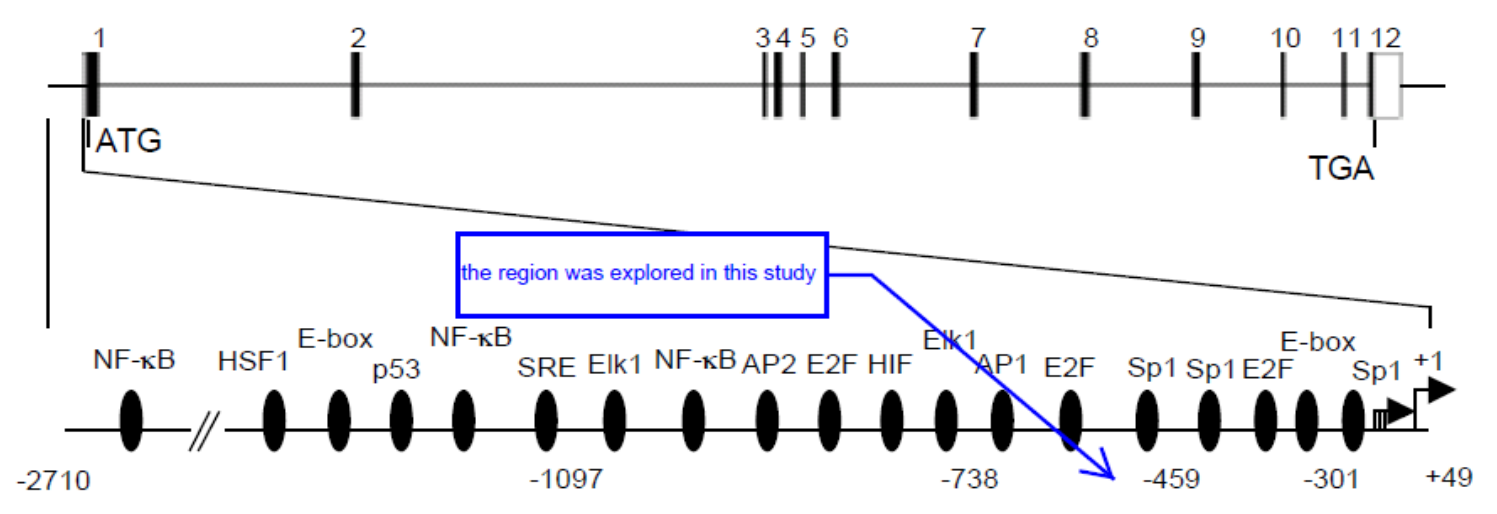

Figure 1. Schematic diagram of AEG-1 promoter.

The negative regulatory region of the AEG1 promoter (accession number: AF411226) was sequenced to investigate genetic variants in DNA samples obtained from the 50 cases. Using the Polymerase Chain Reaction (PCR)-sequencing method, the distribution of promoter variants was determined. Briefly, the region was amplified with the following primers:
Forward 5' -

CCACCAGGGAGAAAAAGCG -3'

Reverse 5'-

GAAGGCGTCCACCAATTAAC -3'.

Most human gene promoters contain $\mathrm{G}+\mathrm{C}$ sequences that are very difficult to amplify. In this study, we propose an improved PCR method to be used for successful amplification of the AEG-1 gene promoter region that exhibit $>70 \% \mathrm{G}+\mathrm{C}$ content in a 
sequence of approximately $238 \mathrm{bp}$, using touchdown-PCR and co-activator Dimethyl sulfoxide (DMSO) (SAMAEI et al., 2013). The touchdown-PCR was carried out on Corbett Thermal Cycler using the following conditions: an initial denaturation at $96^{\circ} \mathrm{C}$ for $7 \mathrm{~min}$, followed by 16 cycles of $94^{\circ} \mathrm{C}$ for $1 \mathrm{~min}, 60^{\circ} \mathrm{C}\left(0.5^{\circ} \mathrm{C}\right.$ decrease per cycle) for $45 \mathrm{sec}, 72^{\circ} \mathrm{C}$ for $1 \mathrm{~min}$, then another 15 cycles of $94^{\circ} \mathrm{C}$ for $1 \mathrm{~min}, 52^{\circ} \mathrm{C}$ for $45 \mathrm{sec}, 72^{\circ} \mathrm{C}$ for $1 \mathrm{~min}$, and a final extension step at $72^{\circ} \mathrm{C}$ for 7 min. The PCR products were separated on $2 \%$ agarose gels in Tris- base-EDTA (TBE) buffer stained with DNA-safe and visualized by Gel Doc Imaging System. All sequencing data was produced by the Genomic Analysis Facility (PuiaGostar Gene, Tehran, Iran) Chromas software (SAMAEI et al., 2013).

In this study DNA was detected by touchdown PCR in 100 patient samples were recruited from the various Provinces of Iran that their ages were in the range of 50-60 years. Comparative analysis between the ratio of absorbance at wavelengths of 260 and $280 \mathrm{~nm}$ was performed (Table 1), and the results showed average ratios obtained in the range of 1.7 were suitable for DNA analysis. To ensure more, it was followed by electrophoresis (Figure 2).

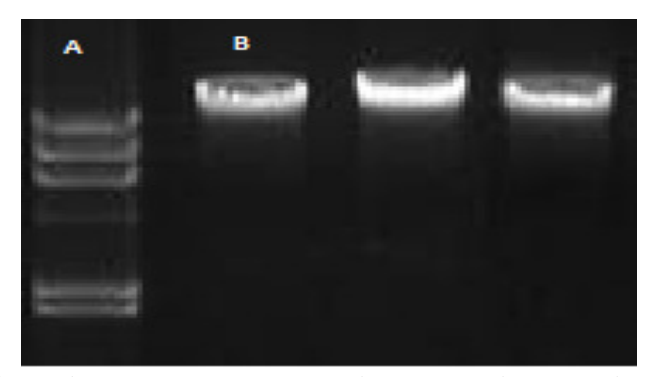

Figure 2. Genomic DNA was analyzed on $1 \%$ agarose gel. A: Marker, $1 \mathrm{~Kb}$ DNA step ladder marker, B:

Genomic DNA isolated from HCC tissues.

Table 1. Spectroscopy of DNA extracted from blood samples randomly

\begin{tabular}{lll}
\hline (OD) 260/280 & Density $(\mathbf{n g} / \boldsymbol{\mu l})$ & Sample name \\
\hline 1.8 & 470.4 & HCC08 \\
1.72 & 457.1 & HCC032 \\
1.68 & 322.2 & HCC027 \\
\hline
\end{tabular}

Using the touchdown PCR, the AEG-1 gene promoter was amplified. All samples have a clear runway suitable for sequencing (no non- specific bands and primer dimer, respectively) (Figure 3).

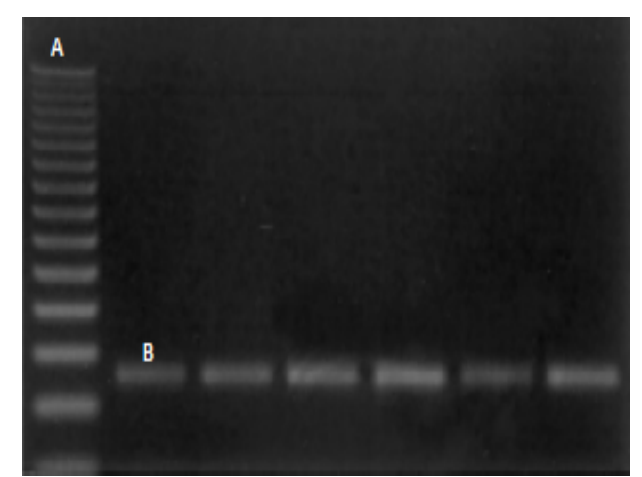

Figure 3. Agarose gel electrophorsis. A: Marker, 100 bp DNA step ladder marker, B: PCR product of AEG-1 promoter.

Data obtained from sequencing were analyzed and acquired for genotyping were then compared with the standard sequence (Figures 4 and 5). Finally, in the patient group, we found two new 
mutations and 2 base displacement in $\mathrm{C}>\mathrm{T}$ (-633) and $\mathrm{G}>\mathrm{C}(-660)$ position of negative regulatory region of the AEG-1 promoter but did not find any nucleotide alteration in control group (Table 2).
However, it was not revealed the statistically significant association between any mutations in this region of the AEG-1 promoter with HCC susceptibility.

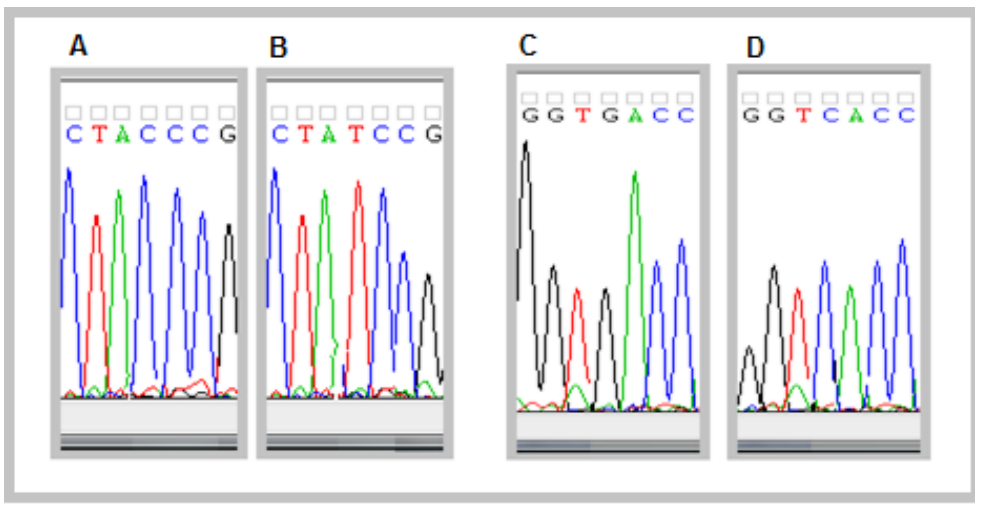

Figure 4. AEG-1 promoter mutation's chromatogram. A: Wild genotype; B: Mutant genotype of -633 location; C: Wild genotype; D: Mutant genotype of -660 location.

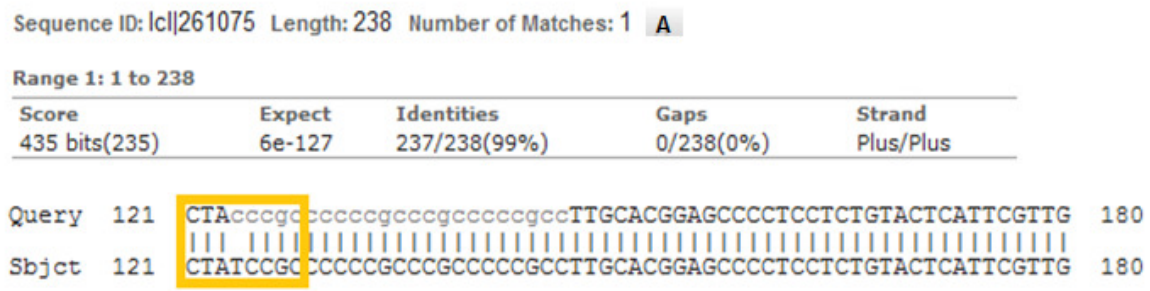

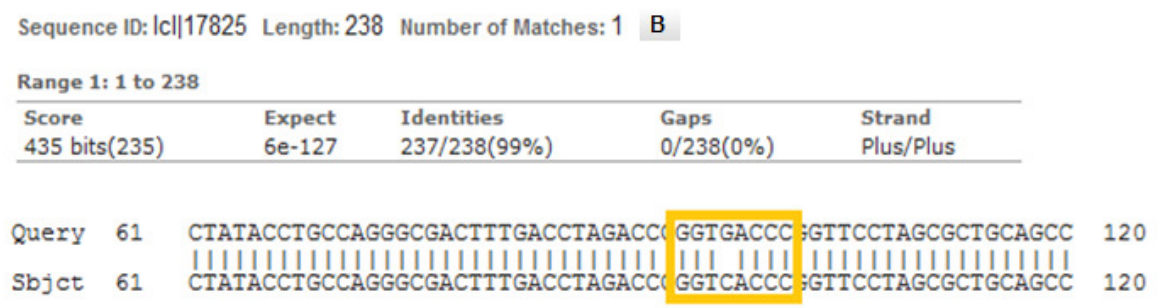

Figure 5. BLAST result of AEG-1 promoter sequence with reference sequence, A; C>T (-633) mutation and B; $\mathrm{G}>\mathrm{C}(-660)$ mutation.

Table 2. Nucleotide changes in patients

\begin{tabular}{|c|c|c|c|c|}
\hline Wild genotype & Mutant genotype & Type of change & Sample code & Position on gene \\
\hline CTACCCG & CTATCCG & Base displacement & P11 & -633 \\
\hline GGTGACC & $\underline{\text { GGTCACC }}$ & Base displacement & $\mathrm{P} 35$ & -660 \\
\hline
\end{tabular}

\section{DISCUSSION}

Based on the in vitro and in vivo studies in animals and expression analysis using patient samples, it is eminently clear that AEG-1 plays a decisive role in the process of tumorigenesis in multiple organs (SARKAR et al., 2009). The purpose of this study is the explorations of the association of AEG-1 promoter negative regulatory region variant with HCC. Previous studies have demonstrated that some tumor suppressor genes and oncogenes are associated with the progression and development of cancer. Genetic variation in these genes from the perspective of cancer monitoring, molecular diagnosis, and treatment is essential (TAVIAN et al., 2000). The most important oncogene of the malignant progression of $\mathrm{HCC}$ is AEG-1 (YOO et al., 2011). According to reports of 
EMDAD et al. (2009) the aggressive tumor formation in nude mice due to the over-expression of AEG-1 in normal immortal cloned rat embryo fibroblasts (CREF). However, in this study, examination of patient samples represented diverse signs of occurrence of cancer-based on the progressive increase in AEG-1 expression with grades and stages of cancer and an inverse relationship between patient prognosis and AEG-1 expression level. Furthermore, it plays a significant role in metastasis, invasion, chemoresistance, and angiogenesis, all important sign of aggressive cancer (YOO et al., 2011). Human AEG-1 gene that has 12 exons/11 introns is located in chromosome 8q22. Chromosome 8q22 is famous to be a hot spot for genomic alterations in many cancer cells involving breast cancer and HCC (BERGAMASCHI et al., 2006). SNP array probing and microarray $250 \mathrm{~Kb}$ on either side of AEG-1 locus illustrate increased copy number of AEG-1 in HCC (microarray, 32 of 91 tumors with a cut-off of N3; SNP, 36 of 103 tumors with a cut-off of N3), which was significantly associated with the expression level of AEG-1 (YOO et al., 2009a). Therefore, variants of AEG-1 may present to be potential indicators of HCC development, disease progression, and possible foci for future gene therapy. Based on this information and the essential role of the promoter in gene expression, negative regulatory region of the AEG-1 promoter that is consisted of putative RAR- $\alpha$ and YY1 binding sites were chosen for mutation analyze. In this current analysis was found two new mutation $\mathrm{C}>\mathrm{T}$ (-633) and $\mathrm{G}>\mathrm{C}(-660)$ in the patient group. But it was not revealed the statistically significant association between any mutations in this region of the AEG-1 promoter with HCC susceptibility. The existence of two mutations in the AEG-1 promoter in HCC patient's (mean age of 59 years old) tumors, that was not associated with $\mathrm{HCC}$ and can be related to the accumulation of mutations in tumor tissue. Genetic instability could be an advantage because the cancer is to progress the process that led to the accumulation of carcinogenic mutants. In this regard, SRIVASTAVA et al. (2012) showed that Nnitrosodiethylamine (DEN) treating of Alb/AEG-1 and wild-type (WT) mice resulted in multinodular HCC with steatotic features and can be associated with modulation of expression of genes regulating invasion and metastasis. However, these studies revealed that by comparing WT and Alb/AEG-1 mice for a period of up to the age of 1 did not identify obvious dysplastic changes in Alb/AEG-1 mice that indicating a pre-carcinogenic initiating event, such as mutagenesis by DEN, might be necessary before AEG- 1 and might contribute to the tumorigenesis process. Also, SRIVASTAVA et al. (2012) suggested AEG-1 provides strong conservation from DNA damage in the hepatocytes resulting in senescence because one of the potential anti-cancer mechanisms is senescence and by blocking senescence, AEG-1 may improve progressively the carcinogenic process (COLLADO AND SERRANO, 2010). In another study conducted by our team, positive promoter regulatory regions of AEG-1 were explored. According to the previous data of sequencing, genetic variations among $11 \mathrm{HCC}$ patients and 3 healthy controls in the AEG-1 positive region were reported (GHOLIPOUR et al., 2015a). There, one novel SNP was found in the binding site of activator protein-2 (AP2) transcription factor (-483 A to C), which had an association with susceptibility to $\mathrm{HCC}(\mathrm{P}=0.05)$; however, no association was found for other variations that observed (MOTALLEB et al., 2014). In breast cancer, genetic variation in the gene introns and exons by Liu and colleagues was investigated using direct sequencing method, and multiple mutations associated with breast cancer were reported. Three new mutations associated with this cancer in intron 7 and exons 6 and 7 were found (LIU et al., 2011). But no mutation associated with the breast cancer has been found in the promoter region of AEG-1. The lack of variants associated with HCC in AEG-1 negative regulatory promoter noted in this study and the absence of transcriptional silencing rules out the hypothesis concerning the role of the gene variants in HCC susceptibility. This is in agreement with results of a similar study in which AEG-1 promoter upstream of the start codon was screened for mutations in colon cancer collected from the Chinese population (QI et al., 2010). These data suggest that the promoter mutations located in this region of AEG-1 are not responsible for $\mathrm{HCC}$ susceptibility, and thus argue against their possible role in HCC development. In the one hands, this two new variants in -633 and 660 regions are somatic mutations that maybe plays a role in transforming normal cells into cancerous cells and the other hands they may be created, depends on the mutation rate that was increased in cancer cells. Over-expression of the AEG-1 in HCC patient may be accompanied by some other reason such as, A) another regional mutation of AEG-1 gene sequence, e.g. positive regulatory regions in promoter, exons and introns, B) over-expression of transcription factors, that have a binding site in AEG-1 promoter, C) alternation of signaling pathway that are related to $\mathrm{HCC}$ progression. Second, it may simply be that there is very little 
relationship between the AEG-1 promoter genetic variants and the risk of HCC. Since the genome has been altered by years of aging and environmental factors, these new mutations that we found maybe are the result of this agent. Based on the previous data (GHOLIPOUR et al., 2015a,b), AEG-1 positive region has a significant role in aggressive cancer, but our understanding of the functions of the AEG-1 negative promoter region is still very limited, and its exact role in AEG-1 over-expression and relation remains unknown. Therefore, in this study, the association of AEG-1 promoter negative regulatory region with $\mathrm{HCC}$ was investigated and results demonstrated the AEG-1 as a key regulator of the complex network oncogenic pathways, has been mutated (two new mutations) in the position of the
AEG-1 negative regulatory region. So its variants may be responsible for the elevation of AEG-1 expression in HCC patient group because the two mutations in the AEG-1 negative regulatory region could be inhibiting the functional localization the AEG-1 suppressor genes. However, further studies will be required to determine the role of this region, if any, in the expression of AEG-1 gene in HCC tumor.

\section{ACKNOWLEDGMENTS}

This research was supported by Golestan University of Medical Sciences (grant no.:921017162).

RESUMO: Resumo: O gene AEG-1 é um regulador positivo da tumorigênese em células cancerígenas humanas. O gene humano AEG-1 está localizado no cromossomo $8 \mathrm{q} 22$ com 12 exons/11 introns. O cromossomo 8q22 é conhecido por ser um hotspot para alterações genômicas em várias células cancerígenas que envolvem o CHC. O objetivo do estudo foi avaliar a associação entre a região reguladora negativa das mutações do promotor AEG-1 e a suscetibilidade genética ao carcinoma hepatocelular. A região reguladora negativa do promotor humano AEG-1 foi avaliada em um total de 50 pacientes iranianos com carcinomas hepatocelulares (CHC). Para investigar os polimorfismos do promotor AEG-1, utilizou-se o método de sequenciação por PCR. Neste estudo foram encontradas duas novas mutações C>T (-633) e G>C (-660) no grupo de pacientes. Mas não foi revelada a associação estatisticamente significante entre quaisquer mutações nessa região do promotor AEG-1 com suscetibilidade ao CHC. De acordo com os dados apresentados, podemos dizer que a região reguladora negativa das mutações do promotor AEG-1 não demonstrou relevância significativa com o carcinoma hepatocelular. Recomendamos estudos adicionais sobre a eficácia do promotor AEG-1 no direcionamento terapêutico do CHC.

PALAVRAS-CHAVE: Gene AEG-1. Carcinoma hepatocelular. Mutação. Promotor. Região reguladora.

\section{REFERENCES}

ALVES, P. R. C.; ALVES, D.; GUZ, B.; MATOS, C.; VIANA, M.; HARRIZ, M.; TERRABUIO, D.; KONDO, M.; GAMPEL, O.; POLLETTI P. Advanced hepatocellular carcinoma review of targeted molecular drugs. Annals of Hepatology, v. 10, p. 21-27. 2011.

BERGAMASCHI, A.; KIM, Y.H.; WANG, P.; SØRLIE, T.; HERNANDEZ-BOUSSARD, T.; LONNING, P. E.; TIBSHIRANI, R.; BØRRESEN-DALE, A. L.; POLLACK, J. R. Distinct patterns of DNA copy number alteration are associated with different clinico pathological features and gene-expression subtypes of breast cancer, Genes, Chromosom and Cancer, v. 45, p. 1033-1040, 2006.

BHUTIA, S. K.; KEGELMAN, T. P.; DAS, S. K.; AZAB, B.; SU, Z. Z.; LEE, S. G.; SARKAR, D.; FISHER, P. B. Astrocyte elevated gene-1 induces protective autophagy, Proceedings of the National Academy of Sciences of the United States of America, v. 107, p. 22243-22248, 2010. http://dx.doi.org/10.1073/pnas.1009479107

COLLADO, M.; SERRANO, M. Senescence in tumours: evidence from mice and humans, Nature Reviews Cancer, v. 10, p. 51-57, 2010. http://dx.doi.org/10.1038/nrc2772

EL-SERAG, H. B. Hepatocellular carcinoma, New England Journal of Medicine, v. 365, p. 1118-1127, 2010. http://dx.doi.org/10.1056/NEJMra1001683 
EMDAD, L.; LEE, S. G.; SU, Z.Z.; JEON, H. Y.; BOUKERCHE, H.; SARKAR, D.; FISHER, P. B. Astrocyte elevated gene-1 (AEG-1) functions as an oncogene and regulates angiogenesis, Proceedings of the National Academy of Sciences of the United States of America, v. 106, p. 21300-21305, 2009.

http://dx.doi.org/10.1073/pnas.0910936106

GHOLIPOUR, N.; JAVEHERI, M.; NADERI, M.; MOTALLEB, G.; PORNOUR, M.; SAMAEI, N. M. Evaluation of astrocyte elevated gene-1 expression in Iranian hepatocellular carcinoma patients, Journal of Molecular Pathophysiology, v. 1, p. 25-36, 2015.

GHOLIPOUR, N.; NADERI, M.; MOTALLEB G. R.; SAMAEI, N. M. Characteristics of astrocyte elevated gene-1 in cancer progression, Journal of Molecular Pathophysiology, v. 1(2), p. 28-43, 2015.

LEE, S. G.; SU, Z. Z.; EMDAD, L.; SARKAR, D.; FISHER, P. B. Astrocyte elevated gene-1 (AEG-1) is a target gene of oncogenic Ha-ras requiring phosphatidylinositol 3-kinase and c-Myc, Proceedings of the National Academy of Sciences of the United States of America, v. 103, p. 17390-17395, 2006. http://dx.doi.org/10.1073/pnas.0608386103

LIU, X.; ZHANG, N.; LI, X.; MORAN, M. S.; YUAN, C., YAN, S.; JIANG, L.; MA, T.; HAFFTY, B. G.; YANG, Q. Identification of novel variants of metadherin in breast cancer, PloS. ONE, v. 6, p. 17582, 2011. http://dx.doi.org/10.1371/journal.pone.0017582

KANG, D. C.; SU, Z. Z.; SARKAR, D.; EMDAD, L.; VOLSKY, D. J. FISHER, P. B. Cloning and characterization of HIV-1-inducible Astrocyte elevated gene-1, AEG-1, Gene, v. 353, p. 8-15, 2005. http://dx.doi.org/10.1016/j.gene.2005.04.006

MOHEBBI, M.; MAHMOODI, M.; WOLFE, R.; NOURIJELYANI, K.; MOHAMMAD, K.; ZERAATI, H.; FOTOUHI, A. Geographical spread of gastrointestinal tract cancer incidence in the Caspian Sea region of Iran: Spatial analysis of cancer registry data, BMC Cancer, v. 8, p. 137, 2008. http://dx.doi.org/10.1186/1471-24078-137

MOTALLEB, G.; GHOLIPOUR, N.; SAMAEI, N. M. Association of the human astrocyte elevated gene-1 promoter variants with susceptibility to hepatocellular carcinoma, Medical Oncology, v. 31, p. 916, 2014. http://dx.doi.org/10.1007/s12032-014-0916-5

PIKOR, L. A.; ENFIELD, K. S. S.; CAMERON, H.; LAM, W. L. DNA extraction from paraffin embedded material for genetic and epigenetic analyses. Journal of Visualized Experiments, v. 49, p. e2763, 201. http://dx.doi.org/10.3791/2763

POON, T. C.; WONG, N.; LAI, P. B.; RATTRAY, M. P. J.; SUNG, J. J. A tumor progression model for hepatocellular carcinoma: Bioinformatic analysis of genomic data, Gastroenterology, v. 131, p. 1262-1270, 2006. http://dx.doi.org/10.1053/j.gastro.2006.08.014

QI, Y.; LEI, W.; MEI-JIN, H.; BEN-QIANG, R.; JUN, H.; XIAO-JIAN, W.; HUAN-LIANG, L.; PING, L.; JIAN-PING, W. Investigating the correlationbetween MTDH/AEG-1 gene 5'-UTR polymorphism and geneticsusceptibility to sporadic colorectal cancer, Chinese Journal of Pathophysiology, v. 26, p. 1468-1473, 2010.

SAIEDI HOSSEINI, S. Y. Risk factors and incidence of hepatocellular carcinoma in Southeast Iran, Hepatitis Monthly, v. 11, p. 666-667, 2011. http://dx.doi.org/10.5812/kowsar.1735143X.2137

SAMAEI, N. M.; NADERI, M.; KHAJEH, H.; MORADIPOUR, N.; GHOLIPOUR, N.; ZARGHAMI MOGHADDAM, P. Optimization PCR product of GC richastrocytedelevatedgene 1 promoter, Journal of North Khorasan University of Medical Sciences, v. 5, p. 831-836, 2013. 
SARKAR, D.; EMDAD, L.; LEE, S. G.; YOO, B. K.; SU, Z. Z.; FISHER, P. B. Astrocyte elevated gene-1: far more than just a gene regulated in astrocytes, Cancer Research, v. 69, p. 8529-8535, 2009.

http://dx.doi.org/10.1158/0008-5472.CAN-09-1846

SONG, L.; LI, W.; ZHANG, H.; LIAO, W.; DAI, T.; YU, C.; DING, X.; ZHANG, L.; LI, J. Over-expression of AEG-1 significantly associates with tumor aggressiveness and poor prognosis in human non-small cell lung cancer. Journal of Pathology, v. 219, p. 317-326, 2009.

SRIVASTAVA, J.; SIDDIQ, A.; EMDAD, L.; SANTHEKADUR, P. K.; CHEN, D.; GREDLER, R.; SHEN, X. N.; ROBERTSON, C. L.; DUMUR, C. I.; HYLEMON, P. B.; MUKHOPADHYAY, N. D.; BHERE, D.; SHAH, K.; AHMAD, R.; GIASHUDDIN, S.; STAFFLINGER, S.; SUBLER, M. A.; WINDLE, J. J.; FISHER, P. B.; SARKAR, D. Astrocyte elevated gene-1 promotes hepatocarcinogenesis: novel insights from a mouse model, Hepatology, v. 56, p. 1782-1791, 2012. http://dx.doi.org/10.1002/hep.25868

SUTHERLAND, H.G.; LAM, Y.W.; BRIERS, S.; LAMOND, A. I.; BICKMORE, W. A. 3D3/ lyric: a novel transmembrane protein of the endoplasmicreticulum and nuclearenvelope, which is also present in the nucleolus, Experimental Cell Research, v. 294, p. 94-105, 2004.

TAVIAN, D.; DE PETRO, G.; BENETTI, A.; PORTOLANI, N.; GIULINI, S. M.; BARLATI, S. u-PA and c-MET mRNA expression is co-ordinately enhanced while hepatocyte growth factor mRNA is down-regulated in human hepatocellular carcinoma, International Journal of Cancer, v. 87, p. 644-649, 2000.

http://dx.doi.org/10.1002/1097-0215(20000901)87:5\%3C644::AID-IJC4\%3E3.0.CO;2-W

VAZIRI GOHAR, A.; MOHAMMADI, A. 1-A simple method for DNA extraction from formalin-fixed, paraffin embedded tissue blocks, Protocol. Online. 2009.

YOO, B. K.; EMDAD, L.; SU, Z.Z.; SANTHEKADUR, P.; CHEN, D.; GREDLER, R.; FISHER, P.B.; SARKAR, D. Astrocyte elevated gene-1 regulates hepatocellular carcinoma development and progression, Journal of Clinical Investigation, v. 119, p. 465-477, 2009. http://dx.doi.org/10.1172/JCI36460

YOO, B. K.; EMDAD, L.; LEE, S. G.; SU, Z. Z.; SANTHEKADUR, P.; CHEN, D.; GREDLER, R.; FISHER, P. B.; SARKAR, D. Astrocyte elevated gene-1 (AEG-1): A multifunctional regulator of normal and abnormal physiology. Pharmacology \& Therapeutics, v. 130, p. 1-8, 2011.

YOO, B. K.; GREDLER, R.; VOZHILLA, N.; SU, Z. Z.; CHEN, D.; FORCIER, T.; SHAH, K.; SAXENA, U.; HANSEN, U.; FISHER, P.B.; SARKAR, D. Identification of genes conferring resistance to 5-fluorouracil, Proceedings of the National Academy of Sciences of the United States of America, v. 106, p. 12938-12943, 2009. 